\title{
REBEL KING BHARATH SINGHA AND HIS COINS: BHAUMA-NARAKA LEGEND FOR THE FORMATION OF MATAK KINGDOM

\author{
Sewali Deka $^{1 *}$, Nirupam Khanikar ${ }^{2}$
}

${ }^{1 *}$ Lecturer, DUDE Centre, Gargaon College, Sivasagar, Assam, India; ${ }^{2}$ Senior Chemist, Oil \& Natural Gas Corporation Ltd., Sivasagar, Assam, India.

Email: ${ }^{1 *}$ dr.sewalidk@gmail.com, ${ }^{2}$ nirupamkhanikar@gmail.com

Article History: Received on $20^{\text {th }}$ April 2020, Revised on $10^{\text {th }}$ July 2020, Published on $19^{\text {th }}$ August 2020

\section{Abstract}

Purpose of the study: Moamaria rebel king Bharath Singha of Assam issued coins declaring himself a descendant of Bhagadatta. In the present study, we have discussed the ancestral lineage of the rebel king and the various aspects of his association of Bhagadatta.

Methodology: The ancestral root and genealogy of the Mayamara gurus, the community of the rebel king, based on the biographies and other available sources. Genuine coins issued by Bharath Singha were taken for the present study. Various other primary and secondary sources related to the coinage of Assam, historical events, genealogy, and inscriptions were also analysed, and contents are compared to reach a decision.

Main Findings: Bharath Singha established a kingdom based on the Neo-Vaishnavite faith. He associated himself with the legendary king Bhagadatta of Pragjyotishpura for the legitimation of his rule.

Applications of this study: The study may be applied in analysing the nature of the Moamaria Rebellion.

Novelty/Originality of this study: In the present study we have discussed Moamaria rebel leader Bharath Singha of Assam and his coins. Although a good number of works have been published discussing various aspects of Moamaria Rebellion, no special attention had been given to Bharath Singha.

Keywords: Bharath Singha, Moamaria Rebellion, Coinage, Matak Kingdom, Assam, Legitimation.

\section{INTRODUCTION}

After the fall of the Pala dynasty, the Kamarupa Kingdom disintegrated, and several smaller kingdoms emerged. In such a situation the Ahom Kingdom was established in 1228 AD in the eastern part by Tai prince Sukapha. The Ahoms successfully resisted the Mughal advancement to Assam and maintained the existence of their kingdom for nearly six hundred years. The kingdom was occupied by the British East India Company through the Treaty of Yandabo in 1228 AD defeating the Burmese invaders (Gait, 2018; Goswami, 2012).

Before the occupation by the Burmese, the Ahom kingdom had to face a series of armed revolts spanning over several decades in the second half of the $18^{\text {th }}$ century that weakened the kingdom which in turn opened the way to the Burmese. The rebellion, popularly known as Moamaria Rebellion, was carried out by a section Vaishnavite subjects. The NeoVaishnavism movement initiated by Srimanta Sankardeva (1449-1568 AD) greatly influenced the Assamese society and caused the most influential social revolution in Assam against casteism, polytheism, and idol worship. Before his demise, Sanakardeva nominated his disciple Mahapurush Madhavdeva as his successor. But some of the apostles of Sankardeva were not satisfied with the decision taken by Sankardeva and with the passage of time four sects or samhatis emerged, namely, nika samhati, purush samhati, brahma samhati and kala samhati (Neog, 1965; Sarma, 1966). A new institutional order came to be known as satra, a monastery-like religious and socio-cultural institution, emerged and several such satras were established by the disciples of Sankaradeva following his demise (Saikia, 2018). Gopaldeva, a disciple of Madhavdeva established the kala samhati (Nath, 2014). Aniruddhadeva, a disciple of Gopaldeva, was a prominent exponent of Sankardeva's faith, continued the propagation of the bhakti movement among the socially backward and tribal population of Assam. Aniruddhadeva was one of the prominent preceptors of Neo-Vaishnavism in Assam in the post-Sankardeva period and the cult starting with him popularly came to know as Mayamara Vaishnavism. Some of the remarkable literary works of Aniruddhadeva are the Bhaktimangal Ghosha, the translation of Puranjan Uakhayan chapter of the fourth skandha (canto) of Srimad Bhagavata Puran into Assamese, the Nija-Shastra and the translation of the fifth skandha of Srimad Bhagavata Puran into Assamese (Sarma, 2006). Aniruddhadeva composed more than one hundred and eighty-two gits (lyrics) and gave, for each of them, the particular raga or melody. The orchestral band or Gayan-bayan performed in certain religious functions of the Mayamara societies is an important part of traditional music and dance of Assam (Gogoi, 2019). Moamaria Rebellion was carried out by the disciples of Mayamara Satra. Both the terms Mayamara and Moamaria are used extensively to describe the same section of people and have different views regarding their origin. In general, the term Moamaria denotes the section of people who carried out the famous Moamaria Rebellion and the term Mayamara indicates the cult of Anirudddhadeva. The followers of Mayamara Vaishnavism composed of Mataks, Morans, Chutiyas, Ahoms, Kacharis, Kaivartas, Kalitas, Brahmins, and Brittials; however, the Mataks and the Morans being the largest contributors (Dutta, 2017). Although the term Matak was often used in the chronicles as a synonym for Moamaria rebels or disciples of Mayamara gurus, some of the scholars are of the opinion that the Mataks are one of the original inhabitants of Assam. Mayamara disciples, irrespective 
of their ethnic origin, identified themselves as Matak during the rebellion on the advice of their guru. In Tungkhungia Buranji, the chronicle of the Tungkhuniya kings, the term Moran is used to denote for the rebels (Bhuyan, 1968). Ahoms had the good tradition of writing chronicles from the time of their first king Sukapha in Assam.

Moamarias revolted for the first time during the reign of Ahom king Lakshmi Singha alias Sunyeopha (r. 1769-1780 AD). The rebels installed Ramakanta, son of rebel leader Nahorkhura, as the king in November 1769 AD dethroning Lakshmi Singha. But the Moamaria leaders were inexperienced in statecraft and failed to retain their reign. After overthrowing the Ahom monarchy, the sole aim of the rebel leaders was to be popular among all the subjects, irrespective of their political and religious inclination. Instead, the rebel leaders involved in taking revenge on all those who were on the side of the Ahom monarchy, including the non-Mayamara satras, by killing, looting, and destroying properties, and even forced the non-Mayamara disciples to take initiation by Mayamara guru. Again, Gagini alias Saptabhujdeva, son of Mayamara guru Astabhujdeva, conspired with the help of Gobinda Gaonburha and others to overthrow Ramakanta and occupy the throne himself (Baruah, 2017). The most influential rebel leader Ragho became the Barbarua, but failed to usher a new order. Kuranganayani, widowed wife of former king Rajeswar Singha was also forcefully taken to his harem by Ragho like wives and daughters of many other Ahom nobles. At last, a conspiracy was planned by Ahom royalists with the help of Kuranganayani. Ragho was assassinated in April next year and Lakshmi Singha was reinstalled as the king. The rebel leaders were so overconfident that during the festive season of Bohag Bihu in April, many of the rebels were allowed to go their distant homes helping the royalists in their plan (Dohutia, 2016). Most of the rebel leaders including Ramakanta, many of the rebels, Astabhujdeva, Saptabhujdeva, and many of their family members were executed. Many innocent Mayamara disciples were also killed. The first phase of the rebellion ended resulting in huge losses on the rebel side but occupying the throne by a non-Ahom common man left a longlasting effect. Ahom kings were believed to be the descendants of Indra or Lengdon, the king of heaven, and considered as the sole heir of the royal throne (Gait, 2018). This legend acted for the legitimation of their rule. The trust on the Ahom royal family was so strong that in the absence of a suitable candidate from the royal family, the kingdom was ruled by the nobles keeping the royal throne vacant. Again, few Ahom officers who became extremely powerful fulfilled their aspirations by putting puppet kings on the throne.

After the demise of Lakshmi Singha, his son Gaurinath became the king. During the reign of King Gaurinath Singha alias Suhitpangpha (r. 1780-1795 AD) Moamarias revolted for the second time in April 1783 AD by suddenly attacking and causing devastation in Rangpur and old capital Gargaon. It was pushed back by royal force and resulting mass killing of Moamarias irrespective of their involvement in revolt to excavate any possibility of future rebellion. But that could not diminish their spirit. In 1786 AD, Moamorias rebelled for the third time with more power and enthusiasm. King Gaurinath Singha fled to Guwahati leaving the fate of the kingdom in the hand of his minister Purnananda Buragohain. Four rebel leaders declared themselves as the kings at four different parts within the Ahom kingdom. Harihar Tanti declared himself as the king in the seized part at Japaribhita, an extensive tract from the foot of the Dafla Hills to the Brahmaputra (present Lakhimpur District) and another rebel leader Howha declared independence at Majuli. Mejera alias Sarbananda Singha became king at Bengmara (present Tinsukia District)) and Bharathi alias Bharath Singha became king at Ahom capital Rangpur in 1791 AD (Gait, 2018) with the support of Mayamara guru Pitambardeva. Among these four Matak Kingdoms only the easternmost one, Bengmara, was able to survive. Purnananda Burgohain accepted the autonomy of Bengmara as a policy to satisfy the rebels and to create a buffer with the Burmese. Matibar succeeded his father Sarbananda Singha. In 1805 AD Matibar entered in an agreement with the Ahom Government and maintained a friendly relationship with the Ahom Kingdom. The relationship between the two kingdoms improved in the later stage to such an extent that Kalibar, younger brother of Matibar was recruited as Buragohain during the reign of Ahom king Chandrakanta Singha and sacrificed his life in the hand of the Burmese for the Ahom Kingdom. In 1792 AD, after the death of Howha, Majuli came under Bharath Singha (Dutta, 2017). The part seized by Harihar Tanti and the Kingdom of Bharath Singha later restored into the Ahom Kingdom. Gaurinath Singha entered the capital Rangpur in March, 1794 AD with the help of the British but later shifted the capital to Jorhat. Bharath Singha fled towards the kingdom of Sarbananda Singha but continued issuing coins in his name. In 1799 AD Bharath Singha, while trying to revolt again, was killed in an expedition by Ahom army trained on the British model. The emergence of autonomous Bengmara Kingdom and loss of life of a large section of the population weakened the Ahom kingdom which could not be compensated by anyways. The kingdom that resisted the powerful Mughal advancement for a long time fell into Burmese hand and thereby paved the way to the British rule in Assam.

Moamaria Rebellion has attracted many of the historians and social scientists. Barpujari (1963) analyses the rebellion as an external reflection of accumulated hatred, bitterness, and anger of the common masses. On the one hand, it was against the inhuman policy of repression and economic exploitation and on the other hand against extreme religious discrimination and humiliation. The seed of Moamaria rebellion was sown at the very beginning of Vaishnavism in Assam due to the feeling of hatred of other religious preachers and disciples and oppressions of kings and royal officials for generations (Bhuyan, 1975). Ahom monarchy always tried to suppress the Mayamara Vaishnavism based on religious ideology. This attitude of suppression is analysed as the main reason behind the Moamoaria Rebellion by Neog (1982) and Nath (2008). In a few studies, the socio-economic factors behind the revolt have also been studied (Guha, 1991; Sharma, 1996; Bora, 1998). These scholars have tried to analyse the revolt as a class struggle and commented that the erstwhile paik system of the Ahom regime and the revolt was for the restoration of social, economic and political 
justice to the people by uprooting the exploitative ruling nobility. Gogoi (2016) discusses the role of Bar-raja Phuleswari, queen of Ahom king Siva Singha, for the genesis of the rebellion. Nath (2008) has also emphasised on the presence of ethnic as well as caste elements during the rebellion. Chutiyas and Morans had their kingdoms which had been lost to Ahoms several centuries before, and through the rebellion, these two communities attempted to restore their respective kingdoms. In a recent study, Gogoi (2018) commented that terming Moamaria Rebellion as a peasant movement is nothing but an anachronistic interpretation and shown that ethnocentrism and casteism were the factors acting behind the rebellion.

Both the rebel kings Bharath Singha and Sarbananda Singha opened mints and started issuing gold and silver coins in their name. The rebels destroyed and looted many of the stores of gold and silver under the Ahom king (Bhuyan, 1994; Gait, 2018). The self-proclaimed king Bharath Singha declared himself as Bhagadatta Kulodbhava meaning originated from the clan of Bhagadatta as evidenced by his coins issued in the saka era 1713, 1714, 1715, 1718 and 1719 corresponding to 1791, 1792, 1793, 1796 and $1797 \mathrm{AD}$ (Rhodes \& Bose, 2004). A good number of works are available discussing various aspects of Moamaria Rebellion, but none of the publications has given importance to the association of Bharath Singha with the clan of Bhagadatta.

\section{METHODOLOGY}

With The present study provides a comparative analysis of the genealogy of Mayamora gurus based on the selfintroduction included in the Puranjan Upakhyan by Aniruddhadeva and his charits or biographies. Biographies of the Vaishnavite gurus are written by the disciples and popularly known as Guru Charitra or Guru Charit. These biographies not only provide information on the life and activities of the Vaishnavite saints but also give information relating to genealogy, geography, history, economic condition, social system and culture. There are two biographies available on Aniruddhadeva. The first charit of Aniruddhadeva including vamsavali or genealogy of his successors was written by Chidanandadeva who occupied the position of guru of Mayamara cult from 1868 to 1880 AD. This book was published in 1933 AD with the title Sri Sri Aniruddhadevar Charitra aru Mayamara Gosai Sakalar Vamsawali at the initiative of Hridayananda Goswami, a former satradhikar of the Mayamara Dinjoy Satra. This book opened the door for research on Aniruddhadeva, the Mayamara Vaishnava society and the Moamaria Rebellion (Baruah, 2004). The other charit which was written by Utsavananda Goswami, a former satradhikar of Mayamara Puronimati Satra near Jorhat is unpublished, and the manuscript is in possession of the satra (Hazarika, 2014). The relation of Bharath Singha with the community of the Mayamara gurus has also been analysed based on available historical sources. In addition to catalogues on coins of Assam during the Ahom period, two genuine silver coins of Bharath Singha sourced from locations well within the erstwhile Ahom Kingdom were also examined.

\section{RESULT AND DISCUSSION}

\section{Genealogy of Mayamara gurus}

Family of the first Mayamara guru Aniruddhadeva belonged to Baro-Bhuyan community. Bhuyans of Assam are often prefixed with baro, meaning twelve or many. Baro-Bhuyans of Assam did not belong to a particular cast, instead, they belong to various ethnic groups both indigenous and migrants. Each Bhuyan chief was the administrative and judicial head of a particular tract (Barua, 2014). The genealogy and ancestral root of Aniruddhadeva can be extracted from three different sources. In Puranjan Upakhyan, Aniruddhadeva included his self-introduction, where he describes himself as a son of Gondagiri (Goswami, 1993). He started his genealogy from Mahipal, his great grandfather. It provides no information on the predecessors of Mahipal or any connection with Nepal. According to the charit written by Chidanandadeva, king Sasabindu of Nepal and his son king Bhagadatta were the ancestors of Aniruddhadeva (Goswami, 1933). Bhagadatta had two sons Rambar and Haribar. Rambar migrated to Assam while Haribar remained at Nepal inheriting ancestral properties. Rambar became a Baro-Bhuyan in Assam, and was succeeded by his son Mahipal. According to the charit written by Utsavananda Goswami, Surjyavangsi king Sumitra was the first king of Kaliyuga and the ancestor of Aniruddhadeva (Baruah, 2006; Hazarika, 2014; Ahmed, 2014). Suryasamachar, son of Saumitra, became the king of Nepal. Haribindu, a descendant of Suryasamachar brought to Gaurda by the king of Kanauja. Later, descendants of Haribindu migrated to Assam. According to this biography, Aniruddhadeva was from the tenth generation after Sumitra.

Very little information is available about the early life of rebel leader Bharathi or Bharath, but all the available sources indicate that he was from the community of Mayamara gurus, and was a Mahanta of the Mayamara Satra. Bharath Singha was a grandson of Mahadev, who in turn, a descendant of Sarbanadadeva (Rajkumar, 2000). Sarbanandadeva was the fifth son of Aniruddhadeva. According to Baruah (2017), Pitambar was a descendant of Sarbanandadeva and Bharath was a nephew of Pitambar. Bharath fled to Dafla hills with Pitambar during the massacre of Mayamora mahantas and their family members by the Ahom royal force. After a few years of the killing of Astabhujdeva, Pitambar became the guru and satradhikar of Mayamara Satra with the support of Ahom monarchy. Bharathi, Mejera and many others took initiation by Guru Astabhujdeva (Dahutia, 2016).

The inspection of chronicles and charits we see that the Ahom monarchy had a negative attitude towards the Mayamara gurus and disciples from the very bagging. During the reign of Pratap Singha alias Susengpha (r. 1603-1641 AD) two 
officers of who were disciples of Mayamora Satra had to lose their lives to prove their devotion to their faith in front of the king. After the departure of Aniruddhadeva in 1626 AD, his son Krishnadeva became the guru and established a new satra at Khutiaputa. The present form of performing the gits of Aniruddhadeva through dance and playing of the drum (mridanga) and the cymbal (bhortal) is said to have been introduced by Krishnadeva (Gogoi, 2019). Krishnadeva demised in $1641 \mathrm{AD}$ and then his eldest son Hariramdeva become guru. Hariramdeva occupied the position of guru only for three years and was followed by his brother Nityanandadeva. Nityanandadeva was killed in 1650 AD making a conspiracy during the reign of Surempha alias Bhagaraj (r. 1649-1652 AD). Although Jairamdeva was nominated by Nityanandadeva, with the fear of Ahom monarchy, he took charge formally in 1654 AD only when Jayadhvaj Singha alias Sutamla become the king. King Udayaditya Singha (r. 1669-1673 AD) also forced the Mayamara mahantas to take initiation by a bairagi brought from Brindaban. Jairamdeva passed away in 1683 AD and Jadunandadeva, son of Jairamdeva become the guru, who in turn followed by Baikunthanathdeva. In 1681 AD, Ahom king Godadhar Singha alias Supatpha established the rule of the Tungkhungia clan and adopted the policy of suppression on Neo-Vaishnavism. Gadadhar Singha punished the gurus and disciples of the Vaishnavite sect, and many satras were destroyed and looted. Baikunthanathdeva was executed in $1691 \mathrm{AD}$ on royal order. The following few years passed with the seat of the Mayamara guru vacant. After the passage of Gadadhar Singha, his son Rudra Singha alias Sukhrungpha (r. 1696-1714 $\mathrm{AD}$ ) became the king, and policy towards the satras changed. Chartubhujdeva, son of Baikunthnathdeva, took over the charge of guru in $1696 \mathrm{AD}$. Although Rudra Singha had a progressive political view, he ordered the upper-class Brahmin disciples of Mayamara Satra to accept discipleship at Brahmanic satras. After Rudra Singha, his son Siva Singha alias Sutanpha (r. 1714-1744 AD) became the king. King Siva Singha was predicted by the astrologers that he was under the evil influence of the stars (Chatra-Bhanga-Yoga), as a result of which he might have lost his throne (Gogoi, 2016). The king, therefore, handed overall power to his queen Phuleswari alias Pramatheswari Devi at the advice of his Shakta guru Krishnaram Bhattacharyya conferring the title Bar-raja (king over the king). Bar-raja Phuleswari forced Chartubhujdeva and other Vaishnavite gosains and mahantas to offer oblations to the goddess Durga and smeared sacrificial blood on their forehead, which was against the basic principles of Neo-Vaishnavism. She even ordered the execution of Chartubhujdeva, but barred from doing so by the king on the advice of Krishnaram Bhattacharyya. This incident further deteriorated the relation between Ahom monarchy and Mayamora Satra. According to Gogoi (2016), the act of Phuleswari was not her desire; instead, she followed the policy of the former Ahom Kings. After the demise of Chartubhujdeva in $1747 \mathrm{AD}$, Astabhujdeva became the guru. Astabhujdeva was one of the most influential gurus of the Mayamara cult after Aniruddhadeva. The first phase of Moamaria rebellion occurred during the time of Astabhujdeva. Astabhujdeva and his son Saptabhujdeva were executed in 1770 AD due to their involvement in the rebellion during the reign of King Lakshmi Singha. Later, Pitambardeva was installed as the satradhikar of the Mayamara Satra by King Gaurinath Singha.

\section{Coins of King Bharath Singha:}

For the present study, we have taken two silver coins (Figure 1) issued by Bharath Singha. The legends on the coins are in Sanskrit with the Assamese script. The details of the legends of the two coins are given in Table 1.
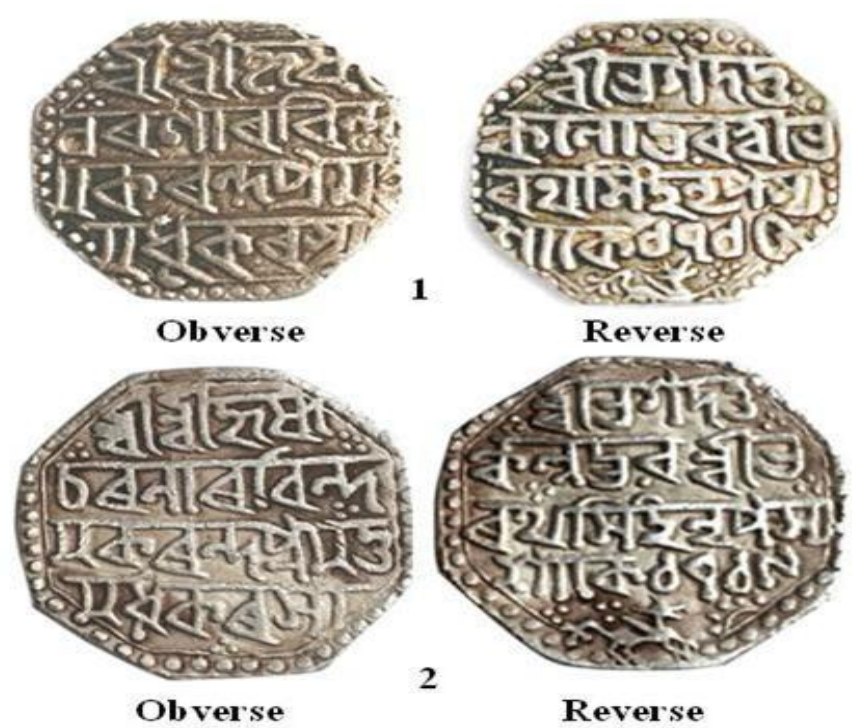

Figure 1: Two silver coins of Bharath Singha (Coin 1: Weight $11.345 \mathrm{~g}$, Diameter $23.10 \mathrm{~mm}$; Coin 2: Weight $11.129 \mathrm{~g}$, Diameter $23.98 \mathrm{~mm}$ )

Source: Author's personal collection 
Table 1: Legend details of the two coins of Bharath Singha

\begin{tabular}{lll}
\hline No. & Obverse & Reverse \\
\hline 1 & Sri Sri Krishna/ Charanārabinda/Makaranda & $\begin{array}{l}\text { Sri Bhagadatta /Kulodbhava Sri Bharatha } \\
\text { Singha Nripashya/Sake 1715 }\end{array}$ \\
\hline 2 & Same as above & $\begin{array}{l}\text { Same as above with the year 1719 and a } \\
\text { mistake in the word kulodbhava }\end{array}$ \\
\hline
\end{tabular}

The obverse legend may be translated as intoxicated with the nectar of the lotus of the feet of Sri Sri Krishna, while the reverse legend may be translated as King Sri Bharatha Singha born in the family of Sri Bhagadatta (Dutta, 1994; Sirkar, 2008). Legends and other characteristics the coins are the same as reported by Dutta (1984) and Rhodes \& Bose (2004). From the obverse legend, it is clear that Bharath Singha declared himself as a worshipper of Lord Krishna. Krishna or Vishnu is the only god worshipped by the Neo-Vaishnavites of Assam, particularly the Mayamara Vaishnavites, who strictly follow the principles of Sanakardeva's Eka Sarana Hari Nama Dharma. Most of the contemporary coins issued by Ahom kings had invocation to Hara-Gauri and Siva except few scarce coins having invocation to Lengdon, a deity of traditional Ahom belief, minted in the occasion of coronation. Coins issued by the two rebel kings are not only remarkable archaeological evidence but also an important tool for the study of the nature of the Moamaria Rebellion. Among the four self-proclaimed rebel kings of the third phase of Moamaria Rebellion, only Bharath Singha and Sarbananda Singha were able to issue coins in their name. Both Bharath Singha and Sarbananda Singha followed the same size, shape and weight standard for coins that were followed by the Ahom kings, to make them acceptable to the people. In both the coins studied, Bharath Singha used the title Bhagadatta Kulodbhava declaring himself a descendant of Bhagadatta. King Sarbananda Singha of Bengmara also issued coins with an invocation to Lord Krishna. Still, he did not declare himself as Bhagadatta Kulodbhava rather issued coins with the title Swargadeva like the Ahom Kings (Rhodes \& Bose, 2004). Although Dutta (1994), while reporting on a rare gold coin of Bharath Singha, commented that Bharath issued his coins claiming his ancestral root with king Bhagadatta of Nepal, numismatists think that Bhagadatta mentioned in the coins of the rebel king was the legendary king of Pragjyotishpura (Rhodes \& Bose, 2004). Assam was known as Kamarupa with its capital at Pragjyotishpura in ancient times. The dragon-like winged lion symbol used by the Ahom Kings is clearly seen on the reverse side of both the coins. This mythical figure was used as the emblem of the Ahom Kingdom and is now available in the Vaishnavite monasteries of Assam (Sarma, 2017).

\section{Bhauma-Naraka legend and legitimation of royal dynasties:}

The earliest king of Pragjyotishpura or Kamarupa was a non-Aryan named Mahiranga of the Danava dynasty. Mahiranga is the Sanskritised from Bodo origin name Mairang. The king and the peoples were thus Mlecchas of Mongoloid origin. Naraka, an asura, conquered Pragjyotisha overthrowing King Ghataka and started the reign of a new dynasty in Kamarupa (Barua, 2014). Bhagadatta, an illustrious king of Pragjyotishpura and son of Naraka, was the great hero of Mahabharata whose daughter was married to Duryodhana, the eldest Kaurava. Thus in the Kurukshetra war, Bhagadatta took the side of the Kauravas. Bhagadatta considered Krishna as his enemy as his friend Jarasandha was killed by Krishna. Bhagadatta was so powerful that the writer of the epic made Arjuna, with Lord Krishna as the charioteer of his ratha, as the defeater of Bhagadatta. The legend of Naraka and Bhagadatta is firmly attached to the ancient Kamarupa Kingdom and three royal dynasties in the early medieval period, namely, Varmans, Salastambhas, and Palas claimed to descend from Naraka (Choudhury, 1959). In the famous Nidhanpur copperplate inscription King Bhaskaravarman of Kamarupa, the king claimed to be a descendant of Naraka and Bhagadatta. According to this copperplate, the genealogy of King Bhaskaravarman was started with king Naraka. After Naraka, Bhagadatta became the king, who in turn followed by Vrajadatta. After Vrajadatta the kingdom was ruled by different rulers of this family for three thousand years. Then Pushyavarman became the king (Bhattacharya, 1914). Pushyavarman (r. 350-374 AD), a contemporary of Samudragupta, was the first king of Varman dynasty of Kamarupa. Bhaskaravarman (r. 600-650 AD) was the most illustrious ruler of the Varman dynasty. Still, after his death, Salastambha acquired the power through a Mleccha revolution and established the reign of the Salastambha dynasty (650-900 AD). The Dubi Copper-plate Inscription of

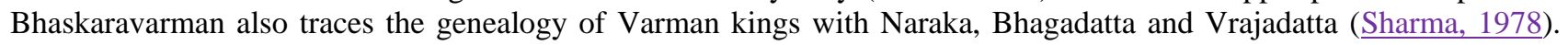
The Hayunthal Copperplate Grant of Harjaravarman (r. 815-832 AD), a king from Salastambha dynasty, mentions himself as a descendant of Bhagadatta (Bhattacharya, 1931; Lahiri, 1991). The Tezpur Copperplate Grant of King Vanamalavarman of Salastambha dynasty also indicates the genealogy of the Salastambha kings with Naraka and

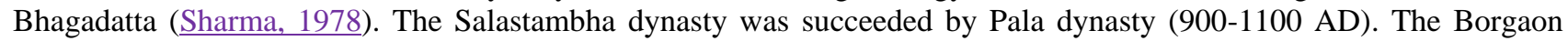
copperplate inscription of Ratnapala (r. 920-960 AD) states that after the twenty-first ruler of that dynasty, Tyagsingha, that died without leaving any heir, Brahmapala was nominated as the king due to his relationship with Naraka (Bhattacharya, 1931; Sharma, 1978; Lahiri, 1991). Brahmapala was the first king of Pala dynasty and father of Ratnapala.

Harsacharitra of Banabhatta describes Naraka as a Bhauma, son of Bhumi or Mother Earth, and Bhagadatta was the anvaya (line of succession) of Naraka (Kakati, 1948). According to Kalika Purana, Naraka was the son of Earth and Vishnu. Naraka was nurtured by her mother in infancy but was reared by Aryan king Janaka of Videha. Naraka gradually became a fierce fighter and well versed in Vedas and a devotee of the God Vishnu. Later Naraka changed his 
attitude when he came under the influence of Banasura, King of Sonitpur (modern Tezpur), and became the initiator of the Shakta cult (Acharyya, 1987; Saikia, 2018).

Claiming ancestral lineage with Naraka and Bhagadatta helped in the legitimisation of Varman, Salastambha, and Pala dynasties of early medieval Assam but after the disintegration of Kamarupa Kingdom followed by the advent of the Ahoms interrupted the continuation of the legend. Bharath Singha intended to re-establish this lost lineage, thereby attempting to legitimise his rule and trying to raise a moral challenge in front of the Ahom royal dynasty. But the Mayamara gurus of post-Moamaria Rebellion had taken it differently. The gurus believed that their ancestors migrated from Kanauj as stated in the charits. Definitely, this migration would be much later than the time of Bhagadatta. Moreover, being true Vaishnavites, the Mayamara gurus might not be satisfied with the asura lineage of their ancestors and also, the fact that they took the side of Kauravas against the Pandavas and Lord Krishna in the Kurukshetra war. Therefore, the creation of a story with a different King Bhagadatta became necessary which coincides with their migration into Assam and also supports the claim of Bharath Singha. Therefore, we could not find any king named Bhagadatta in Nepal medieval history. Considering $1553 \mathrm{AD}$ as the birth year of Aniruddhadeva in an approximate time of ten generations above there was no part in Nepal ruled by any king named Sumitra or Suryasamachar (Baruah, 2006). The difference in the names of the ancestors in the two biographies indicates that legends were not passed orally among generations rather created by the authors. However, both the biographies associate Kanauj and Nepal to the ancestors of the Mayamara gurus. It is possible that during the Turkish aggression in India, ancestors of Aniruddhadeva might be pushed from Kanauj to Nepal, where they occupied a large part of the land, and later moved to Assam. Although, Dutta (1994) previously of the opinion that Bhagadatta stated in the coins of Bharath Singha is the King Bhagadatta of Nepal, later admitted that some of the contents of the biographies are based on unscientific grounds (Dutta, 2017).

\section{CONCLUSION}

The whole period of Bharath Singha as king accompanied by the struggle for survival of his kingdom. Neither a stable economy within the kingdom nor any trade with neighbouring kingdoms was possible in such an unstable political condition. If required, he seized coins from Ahoms could easily fulfill any economic need. The reason for issuing coins by Bharath Singha was thus not economic but to create a reputation of his family. In medieval Assam, gold was extracted from the sand in the rivers and silver was brought from Tibet as no silver mines within the Ahom kingdom (Kalsi, 2005; Kalita, 2019).

The reputation of a dynasty is an important factor in which its acceptability as a royal dynasty depends. The Brahmins projected and popularized the ruling tribe as the ruling caste (Kshatriya) to legitimise their rule. It was a common phenomenon in tribal polities of northeast India (Singh, 1985). While the earlier three dynasties claimed themselves as descendants of Naraka and Bhagadatta, Ahom kings were considered as the descendants Indra or Lengdon. Yogini Tantra, a sixteenth-century Sanskrit text, describes the birth of Viswasingha, the first king of the Koch dynasty, from the union between Shiva and Hira, a Koch wife of Haria Mech for the same purpose (Barman, 2014). In a recent article, focusing on the Chutiyas and the Dimasas, Shin (2020) has discussed how the descendants of demons were finally approved as kshatriyas and how deviation from the traditional demonic lineage occurred. The asura lineage of Chutiya kings, explicitly mentioned as suraripuvamśa in the Dhenukhana inscription dated 1392 AD, was replaced with the lineage with king Bhīsmaka, the father-in-law of Krishna. Dimasa kings initially claimed to be Hachengcaha Vamsaja (descendants of Hachengcha) in their coins, referred to as hedamvädhipati (Lord of Heramba) in the rock-cut inscriptions of later period. A genealogy reaching to Ghațotkaca, son of Bhima and Hidimba, was created for the Dimasa kings. After shifting the capital from Maibong to Khaspur, a place already inhabited by other communities, Hachengcha lineage had limited appeal outside the Dimasas and was no longer conducive to legitimising their position.

For the two rebel kings Sarbananda Singha and Bharatha Singha, it was needed that their families must have some superiority or divine origin. Sarbananda Singha declared himself to be a Chutiya (Buruk branch of the Chutiyas). Thus the purpose of legitimation was easily fulfilled for King Sarbananda Singha by associating him with legendary Chutiya kings (Dohutia, 2016). Gogoi (2018) stated that the assertion of Bharath Singha was the way of the revival of the lost Baro-Bhuyan glory of the past fulfilling the unsuccessful dream of Saptabhujdeva. But we strongly believe that Bharath Singha looked beyond the Baro-Bhuyan glory attached to his clan. As Bharath Singha was not related ethnically to any of the contemporary royal dynasties of Assam, he intended to revive the Bhauma-Naraka legend, that legitimised three royal dynasties Kamarupa in the early medieval period. Inscriptions of the Salastambha dynasty do not show any lineage of its rulers with the Varman rulers, instead, they directly associate them with Naraka and Bhagadatta (Shin, 2011). In the same line, King Bharath Singha associated himself directly with legendry King Bhagadatta without creating any lineage with the royal dynasties of medieval Assam.

\section{LIMITATION AND STUDY FORWARD}

Coins are the only evidence left by Bharath Singha which associates him with Bhagadatta. The intension of a section of rebels to start a new royal dynasty based on the Bhauma-Naraka legend may be analysed as a factor behind Moamaria Rebellion, but it needs further critical study. 


\section{ACKNOWLEDGEMENT}

The authors are grateful to Prof. Dambarudhar Nath, former Sri Sri Aniruddhadeva Chair Professor of Dibrugarh University and S. K. Bose, Trustee, Institute Of Northeast India Studies, Kolkata, for their support. The authors confirm that the paper does not contain any conflict of interest.

\section{AUTHORS CONTRIBUTION}

The paper is an outcome of a research carried out by Sewali Deka. She has done the required literature survey and also corresponding with journal editors. Nirupam Khanikar contributes with the numismatic part in the paper.

\section{REFERENCES}

1. Acharyya, N. N. (1987). A brief history of Assam: From earliest time to the year 1983. Omsons Publications.

2. Ahmed, M. (2014), Sri Sri Aniruddhadeva aru ujoni Asomor samaj sangathan [Sri Sri Aniruddhadeva and upper Assam's social institutions]. In J. Nath (Ed.), Sri Sri Aniruddhadeva, (89-103). Srimanta Sankardeva Sangha.

3. Barman R. K. (2014) State Formation, Legitimization and Cultural Change: A Study of Koch Kingdom, The NEHU Journal, 12(1), 17-35. https://www.nehu.ac.in/public/assets/files/journals/NEHUJournalJan June2014_Art2.pdf

4. Barpujari, H. K. (1963). Assam in the days of company, 1826-1858 A critical and comprehensive history of Assam during the rule of the East-India Company from 1826-1858. Lawyer's Book Stall.

5. Barua, K. L. (2014). Early history of Kamarupa. Bhabani Books.

6. Baruah, B. B. (2017). Moran buranji sar [An outline of Moran history]. Jatiya Prakashan Sangha.

7. Baruah, S. L. (2004, November 12), Revisiting the Vaishnav era. The Telegraph. https://www.telegraphindia.com/states/north-east/revisiting-the-vaishnav-era/cid/1552594

8. Baruah, S. L. (2006), Sri Sri Aniruddhadeva: A biographical sketch and a short review of his teachings. In S. L. Baruah (Ed.), Life and teaching of Sri Sri Aniruddhadeva, (167-197). Dibrugarh University.

9. Bhattacharya, P. (1914). Nidhanpur copper plates of Bhaskarvarman. Epigraphia Indica, 12, 65-79.

10. Bhattacharya, P. (1931). Kāmarūpaśāsanāvalī. Rangpur Sahitya Parisad.

11. Bhuyan, S. K. (Ed.). (1968). Tungkhungia buranji [Tungkhungia chronicle], Department of Historical and Antiquarian Studies in Assam.

12. Bhuyan, S. K. (1975). Swargadew Rajeswar Singha. Publication Board Assam.

13. Bhuyan, S. K. (Ed.). (1994). Satsari Asom buranji [Collection of seven Assam chronicles], Lawyer's Book Stall.

14. Bora, D. (1998). Moamaria gana abhyutthan: Asomor samaj bikasar itihas [Moamaria mass movement: Assam's history of society development]. Banalata.

15. Choudhury, P. C. (1959). The history of civilization of the people of Assam up to 12th century A.D. Department of Historical and Antiquarian Studies in Assam.

16. Dohutia, S. (2016). Moran-Matak-Mayamora: Samaj aru sanskriti [Moran-Matak-Mayamora: Society and culture]. Banalata.

17. Dutta, S. (1984). The Mataks and their kingdom: Castes and tribes of Assam. Chugh Publications.

18. Dutta, S. (1994). A rare gold coin of Bharat Singha: The Matak ruler of Assam, Proceedings of the Indian History Congress, 55, 931-934. www.jstor.org/stable/44143483

19. Dutta, S. (2017). From Mayamara vaishnavism to Moamaria rebellion: An overview of history of Assam. North East India History Association.

20. Gait, E. (2018). A history of Assam. EBH Publishers.

21. Gogoi D. P. (2016). Bar Raja Phuleswari Kunwari: The centre or the periphery in case of Moamoaria rebellion- A study from gender perspective, and some issues. International Journal of Arts, Humanities and Management Studies, 2(12), 55-60. http://ijahms.com/upcomingissue/07.12.2016.pdf.

22. Gogoi, J. (2019). Gayan-Bayan of the Mayamara satra. Research Review International Journal of Multidisciplinary, 4(2), 141-144. https://rrjournals.com/past-issue/gayan-bayan-of-the-mayamara-satra-2/.

23. Gogoi, S. (2018). Mayamara alias Matak-Moran rebellion (1769-1805): As an intellectual anachronism in the politics of peasant movements of Assam. IOSR Journal of Humanities and Social Science (IOSR-JHSS), 23(1), 20-27. https://doi.org/10.9790/0837-2301042027

24. Goswami, C. (1933). Sri Sri Aniruddhadevar charitra aru Mayamara satra gosain sakalar vamsavali [Sri Sri Aniruddhadeva's biography and genealogy of Mayamara satra gosains]. Mayamara Hithadhini Sabha.

25. Goswami, K. D. (1993). Srimadbhagavat. Banalata.

26. Goswami, P. (2012). The history of Assam from Yandabo to Partition 1826-1947. Orient BlackSwan..

27. Guha, A. (1991). Medieval and early colonial Assam: Society, policy and economy. K. P. Bugachi \& Co.

28. Hazarika, S. (2014). Aniruddhadeva: The great saint of Assam. International Journal of Research in Social Sciences, 4(3), 466-477.

29. Kakati, B. K. (1948). The mother goddess Kamakhya. Assam Publishing Corporation. 
30. Kalita, B. J. (2019). Metallurgy in medieval Assam: A study with special reference to gold washing and iron smelting technology. International Journal of Scientific \& Technology Research, 8(11), 2603-2605. http://www.ijstr.org/paper-references.php?ref=IJSTR-1119-25427

31. Kalsi, S. (2005). Coinage and currency of the Ahoms and Jaintiapur: Some reflections on trade. Proceedings of the Indian History Congress, 66, 474-485. www.jstor.org/stable/4414586

32. Lahiri, N. (1991). PreAhom Assam: Studies in the inscriptions of Assam between the fifth and the thirteenth centuries AD. Munshiram Manoharlal Publishers Pvt. Ltd.

33. Nath, D. (2008). The Mataks and their revolt against the state in $18^{\text {th }}$ century Assam searching for ethnoreligious roots. In J. K. Ray \& A. B. Roy (Eds.), Political Roles of Religious Communities in India. (pp. 107124). Institute for Security and Development Policy. https://isdp.eu/publication/political-roles-religiouscommunities-india/

34. Nath, D. (2014). Cult, ideology and conflict: The 'Mayamara' Vaishnavism and social conflict in $18^{\text {th }}$ century Assam, Proceedings of the Indian History Congress. 75, 351-357. www.jstor.org/stable/44158402

35. Neog, M. (1965). Sankaradeva and his times: Early history of vaisnava faith and movement in Assam. Department of Publication Gauhati University.

36. Neog, M. (1982). Socio-political events in Assam leading to the militancy of the Mayamariya vaishnavas. Centre for Studies in Social Sciences Calcutta.

37. Rajkumar, S. (2000). Itihase soaura chashata bacahar [Six hundred years remembered by history]. Banalata.

38. Rhodes N.G., \& Bose S. K. (2004). The coinage of Assam: Ahom period. Library of Numismatic Studies.

39. Saikia, B. (2018). An introduction to the sattra culture of Assam: Belief, change in tradition and current entanglement. Journal of Ethnology and Folkloristics, 12(2), 21-47. https://doi.org/10.2478/jef-2018-0009

40. Sarma, R. (2017). Ngi Ngao Kham -A Mythical Figure of Tai Ahom People of Assam. Journal of Research in Humanities and Social Science, 5(5), 14-18.

41. Sarma, S. N. (1966). The Neo-vaishnavite movement and satra institutions of Assam. Department of Publication Gauhati University.

42. Sarma, S. N. (2006), Asomia sahityar samikhyatmak itihas [Assamese literature's critical history]. Saumar Prakash.

43. Sharma, C. K. (1996). Socio-economic structure and peasant revolt: The case of Moamaria upsurge in the eighteenth century Assam. Indian Anthropologist, 26(2), 33-52. https://www.jstor.org/stable/41919803

44. Sharma, M. M. (1978). Inscriptions of ancient Assam. Department of Publication Gauhati University.

45. Shin, J. E. (2011). Changing dynasties, enduring genealogy: A critical study on the political legitimation in early medieval Kāmarūpa. Journal of Ancient Indian History, 27, 173-187.

46. Shin, J. E. (2020). Descending from demons, ascending to Kshatriyas: Genealogical claims and political process in pre-modern Northeast India, the Chutiyas and the Dimasas. The Indian Economic and Social History Review, 57(1), 49-75. https://doi.org/10.1177/0019464619894134

47. Singh, K. S. (1985). Tribal society in India. Manohar.

48. Sirkar, D. C. (2008). Studies in Indian coins. Motilal Banarsidass Publiishers Pvt. Ltd. 